\title{
The Effect of Sticky Bands on Cankerworm Abundance and Defoliation in Urban Trees
}

\author{
Chanthammavong Noukoun, Gregory Bryant, and Steven D. Frank
}

\begin{abstract}
Defoliation by insects can reduce tree growth, increase mortality, and increase herbivory of neighboring plants. In North Carolina, U.S., fall cankerworms (Alsophila pometaria) and spring cankerworms (Paleacrita vernata) are important early-season defoliators and have become more common in recent years. Female fall and spring cankerworm adults are wingless and climb tree trunks to mate and deposit egg masses. Therefore, sticky bands made by wrapping paper bands around trees and covering them with TangleFoot $^{\text {Tix }}$ can intercept female moths as they climb, preventing oviposition and reducing subsequent larval abundance and defoliation. The authors hypothesize that sticky bands reduce cankerworm larvae and defoliation in the canopy when compared to unbanded trees. To test this hypothesis, cankerworm abundance and defoliation were measured on willow oaks with zero, one, and two bands. It was found that trees with two bands captured an average of 38.69\% more moths than single banded trees. As a consequence, two-band trees had the least larvae in the canopy. It was found that larval abundance, sampled early in the season with trays of soapy water, was correlated with canopy defoliation at the end of the season. However, tree bands did not affect total canopy defoliation. Although many cities use sticky bands as part of cankerworm management, the authors did not find evidence for their efficacy when defoliation is low.

Key Words. Alsophila pometaria; Cankerworms; Defoliation; North Carolina; Paleacrita vernata; Tree Mortality; Quercus phellos; Willow Oak.
\end{abstract}

Defoliation by insects can reduce tree growth, increase mortality, and increase herbivory of neighboring plants (Kulman 1971). Immature leaves are vulnerable to folivorous insects, such as winter moths (Operophtera brumata) and autumnal moths (Epirrita autumnata), because they are more nutritious and have less defensive compounds than mature leaves (Feeny 1970; Feeny 1976; Haukioja et al. 1978; Haukioja et al. 1985). Early-season defoliation of immature leaves can increase susceptibility to secondary pest outbreaks and environmental stress (Rhoades 1983; White 1984; Potter and Redmond 1989). It also forces trees to utilize stored energy sources and nutrients to flush secondary leaves, which can reduce tree growth and survival. For example, early-season defoliation of conifers reduces basal area in proportion to foliage loss (Kulman 1971; Miller and Wagner 1989). Early-season defoliation also increases stem dieback and mortality, and decreases stem diameter of oak seedlings (Wright et al. 1989). Defoliation of oaks by gypsy moth (Lymantria dispar L.) larvae causes a proportional reduction in trunk growth and increases mortality (Minott and Guild 1925; Turner 1963; Naidoo and Lechowicz 2001).

In North Carolina, U.S., two early-season defoliators, fall cankerworms (Alsophila pometaria L.) and spring cankerworms (Paleacrita vernata Peck), cause damage to urban trees (Lyttle 2012; Shaffer 2012). Both species have become more common in recent years, increasing the chance of tree health decline after consecutive years of defoliation. Cankerworms pupate from late spring to late fall (autumn) in the litter and soil beneath trees. Fall and spring cankerworm adults emerge in late fall and early spring, respectively. Both species have wingless moths that climb tree trunks to mate and deposit egg masses of up to 400 eggs into crevasses along the branches in the crown (Porter and Alden 1924). The moths die shortly afterward (Porter and Alden 1924). Larvae hatch in spring, just after bud break, and begin feeding on foliage. After 4-6 weeks, larvae drop from trees to pupate in the soil (Baker 1972; Johnson and Lyon 1991). Larvae disperse by descending from 
silk strands (Johnson and Lyon 1991). Hundreds or thousands of dangling larvae become a nuisance to pedestrians (Hiratsuka et al. 1995; Eirich 2008; Lyttle 2012). They also land on and damage neighboring trees and plants growing beneath host trees (White and Whitham 2000). In many cities, cankerworms have become frequent or even annual pests, which causes concern for urban tree health.

Two methods are available to manage caterpillar pests and reduce defoliation. The foliage of infested trees can be sprayed with an insecticide, such as Bacillus thuringiensis kurstaki, to kill larvae. However, applying insecticide to large trees in densely populated areas is difficult, expensive, and has consequences for non-target organisms and the environment (Cole et al. 1967; Miller 1990; Tobin et al. 2012). Another method, tree banding, has been used to manage cankerworms (Britton 1900; La France and Westwood 2006; Eirich 2008) and other lepidopteran pests, such as gypsy moths (Collins and Hood 1920; Blumenthal and Hoover 1986) and winter moths (Otvos and Hunt 1986) that climb tree trunks as larvae or adults. Tree banding entails wrapping a weatherproof material, such as plastic tape, in a narrow band around a tree trunk and then covering the band with a sticky substance to trap flightless female moths before they reach the tree crown to deposit egg masses (Britton 1900). Sticky bands have been made of many materials, including roofing paper, plastic wrap, and duct tape. Generally, cotton batting, fiberglass insulation, or a similar compressible material is placed underneath the band to fill crevices that would otherwise allow moths to crawl under the band (Otvos and Hunt 1986; Thorpe et al. 1993).

Sticky bands have been recommended and used for centuries to try and reduce damage by lepidopteran pests (Deane 1797; Riley et al. 1883; Britton 1900; Collins and Hood 1920). Yet, research on their efficacy is inconsistent. Bands effectively capture winter moths, gypsy moths, and cankerworms, and often reduce larval abundance in tree canopies, but in most cases do not reduce defoliation (Blumenthal 1983; Blumenthal and Hoover 1986; Otvos and Hunt 1986; Thorpe et al. 1993; Thorpe and Ridgway 1994; La France and Westwood 2006). One study has investigated the efficacy of bands for cankerworm management and found that larval abundance and defoliation were not different between banded and unbanded trees (La France and Westwood 2006). However, the authors point out that larval abundance was very low, making these estimates unreliable (La France and Westwood 2006). The goal of the present study was to test the efficacy of simple tree bands to reduce larval abundance and defoliation of large oak trees by fall and spring cankerworms. No study has shown a benefit to using compressible crevicefilling material beneath bands. So the authors chose to test bands without compressible material, which would be simpler and less expensive to construct and install. No bands, one band, or two bands were arranged for large willow oaks (Quercus phellos) to determine: 1) the seasonal activity of fall and spring cankerworm adults; and how the number of bands affects 2) the number of moths captured; 3) larval abundance in the canopy; and 4) canopy defoliation.

\section{METHODS AND MATERIALS}

This experiment was conducted on the campus of North Carolina State University in Raleigh, North Carolina, U.S. On October 24, 2012, the study authors selected eleven sites that each contained three similar-sized willow oaks. Sites were separated by at least $100 \mathrm{~m}$. Experimental trees at each site were not touching each other or any other tree. Tree DBH was measured and compared among treatments using ANOVA.

Trees within each site were randomly assigned to receive zero sticky bands, one sticky band, or two sticky bands, and labeled by the sticky band treatment they received. Willow oaks were chosen as a study species because they were the primary host for cankerworms in previous seasons and one of the most common tree species in Raleigh. Each trunk was wrapped at breast height with a $7.6 \mathrm{~cm}$ wide band of Tanglefoot Tangle Guard $^{\text {tw }}$ (Contech Inc., Victoria, British Columbia, Canada) banding material. The bands were stretched tightly and held in place with staples. Trees in the two-band treatment had bands placed $15 \mathrm{~cm}$ apart. Tanglefoot ${ }^{\mathrm{mix}}$ (Contech Inc., Victoria, British Columbia, Canada) was applied approximately $5 \mathrm{~mm}$ deep with a putty knife to cover the paper bands. Tanglefoot was reapplied as needed when it became thin from scraping off moths or when bands became covered in debris.

To determine the seasonal abundance and activity of adult female cankerworms, research- 
ers visited trees twice per week from November 26, 2012 until March 28, 2013 to count the female fall and spring cankerworm moths stuck to the sticky bands. Moths were removed from the bands with a stick as they were counted.

To determine how many moths climbed past the first sticky band and to determine if two bands were more effective than one, researchers compared the number of moths captured on trees with one band and two bands over the season with repeated measures ANOVA in the Mixed Procedure of SAS v. 9.3. Site was included as a blocking factor.

To determine how sticky bands affect cankerworm larvae abundance in tree canopies, cankerworm larvae were counted on $4,8,18$, and 25 of April 2013. Two $60 \mathrm{~cm}$ branches were clipped from each tree and beaten onto a $60 \mathrm{~cm} \times 60 \mathrm{~cm}$ white beat sheet. Researchers counted the larvae on the sheet and examined the branch to count larvae that were not dislodged by beating. Larval abundance was also sampled by placing a $30 \mathrm{~cm} \times 60 \mathrm{~cm}$ black tray (filled with $3-5 \mathrm{~cm}$ of soapy water) on the ground below each tree to capture larvae as they dropped from the canopy. The trays were deployed nine times between April 18 and April 30, 2013; the larvae were counted after 12-24 hours. All counts were converted to larvae per 12 hours for analysis. The number of larvae was compared with repeated measures ANOVA in the Mixed Procedure of SAS v. 9.3 (SAS 2012). Site was included as a blocking factor.

To determine how sticky bands affect defoliation, leaf damage was estimated on each branch collected during beat sampling. Two observers estimated the percent of the total leaf area that was missing from each branch. Researchers used the mean of the four observations (two branches with two observations each) as the data for analysis. On May 7, 2013, the total defoliation of each study tree was estimated. Two observers examined each tree from one point of view and recorded the percent of leaf area missing, then moved 180 degrees around the tree and recorded a second estimate. The mean of the four observations was used as the data for analysis. Percent defoliation was compared with ANOVA in the Mixed Procedure of SAS v. 9.3 with site included as a blocking factor.

To determine if percent canopy defoliation was related to larval abundance, researchers tested the correlation between the mean number of larvae counted from beat samples on each tree and percent defoliation. The correlation between the mean number of larvae collected in trays per 12 hours (mean of all dates) from each tree and percent defoliation was also tested. Finally, researchers tested the correlation between the mean larvae collected in trays per 12 hours on the first three sample dates and percent defoliation to determine if early-season abundance predicted end-of-season damage. All correlations were tested in the Corr Procedure of SAS v. 9.3.

\section{RESULTS AND DISCUSSION}

The mean $( \pm$ SEM) DBH did not differ between trees with no bands $(84.8 \pm 13.9)$, one band (73.6 \pm 13.3$)$, or two bands $\left(74.5 \pm 14.2 ; \mathrm{F}_{2,30}=0.21 ; P=0.810\right)$.

The first female fall cankerworm adult was caught on a sticky band on November 30, 2012. Over the next four months, researchers captured 16,498 fall cankerworm moths (Figure 1). The most moths $(2,810)$ were captured on December 28. Forty-one spring cankerworm moths were captured between January 11, 2013 and March 21, 2013.

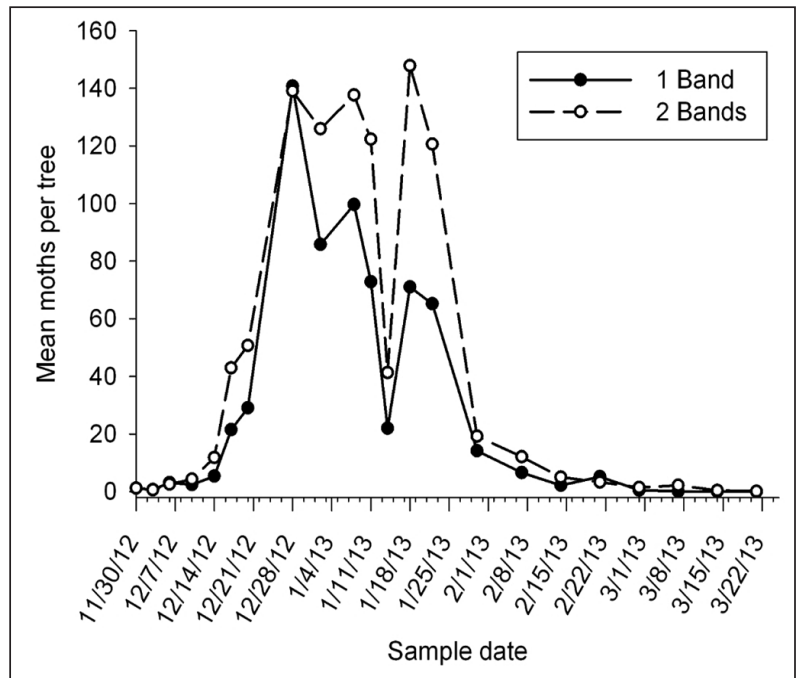

Figure 1. Total capture of female fall cankerworm moths (all sites combined) on sticky bands on each sample date from November 30, 2012 to March 22, 2013.

The number of cankerworm moths captured on sticky bands varied significantly over time $\left(\mathrm{F}_{21,430}\right.$ $=16.30 ; P<0.0001)$, but contrary to the hypothesis, two bands did not capture significantly more moths than one band $\left(\mathrm{F}_{21,430}=1.04 ; P=0.308\right)$, nor was there a significant interaction (Figure 2; $\left.\mathrm{F}_{21,430}=0.85 ; P=0.654\right)$. On two-band trees, $38 \%$ of moths were captured on the upper band. This 


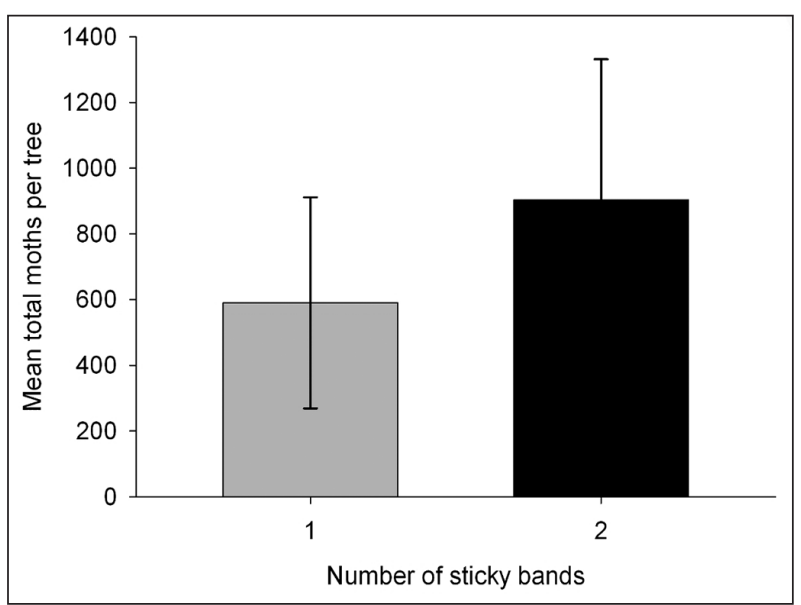

Figure 2. Mean ( \pm SEM) moths captured on trees with one or two sticky bands from November 26, 2012 to March 28, 2013.

shows that cankerworm moths were able to pass the first lower band, but researchers do not know how many also passed the upper band. A similar study found that $20 \%$ of female moths passed the first band and got trapped on a second band $30.5 \mathrm{~cm}$ higher (La France and Westwood 2006). In the current study, the bands did not have compressible material to fill crevices in bark, and researchers did not use caulk or Tanglefoot to fill bark crevices as others have done (e.g., Otvos and Hunt 1986; Thorpe et al. 1993). This may be why a higher percentage of moths were captured on upper bands in the current study than by La France and Westwood (2006), but they do not describe how the bands were constructed in their study.

Cankerworm larvae were first found on March 28, 2013. Cankerworm larval abundance, as assessed by the beat sample method, varied over time $\left(\mathrm{F}_{3,110}=41.98 ; P<0.0001\right)$, but there was not a significant effect of bands on larval abundance $\left(\mathrm{F}_{2,110}=0.73 ; P=0.4836\right)$ or an interaction between date and bands (Figure $3 ; \mathrm{F}_{6,110}=0.56 ; P=0.761$ ). La France and Westwood (2006) also assessed larval abundance by counting larvae on $(30.5 \mathrm{~cm})$ twigs cut from the canopy; they did not find a difference between unbanded and banded trees.

This method may not provide an accurate measure of relative larval abundance because different results were found when larval abundance was measured with plastic trays of soapy water. Larval abundance, as measured by trays, was significantly less on two-band trees than on trees with one or zero bands (Figure 4; $\mathrm{F}_{2,209}=3.70 ; P=0.026$ ) and varied over time $\left(\mathrm{F}_{7,209}=12.49 ; P<0.0001\right)$. There was not a significant interaction between number of bands and date sampled $\left(\mathrm{F}_{14,209}=1.29 ; P=0.213\right)$.

Sticky bands did not affect the amount of defoliation as estimated from $70 \mathrm{~cm}$ branches $\left(\mathrm{F}_{2,50}=1.51\right.$; $P=0.231$ ), but defoliation increased on branches over time $\left(\mathrm{F}_{1,50}=21.08 ; P<0.0001\right)$. There is no significant interaction between band treatment and sampling date on branch defoliation $\left(\mathrm{F}_{2,50}=0.30 ; P\right.$ $=0.746$ ). Cankerworm larvae per branch were significantly, positively correlated with percent defoliation per branch during peak larval abundance on April $18(\mathrm{r}=0.684 ; \mathrm{n}=33 ; P<0.0001)$. There was not a significant correlation on April $25(\mathrm{r}=0.161$; $\mathrm{n}=33 ; P=0.371)$, when larvae were scarce. Can-

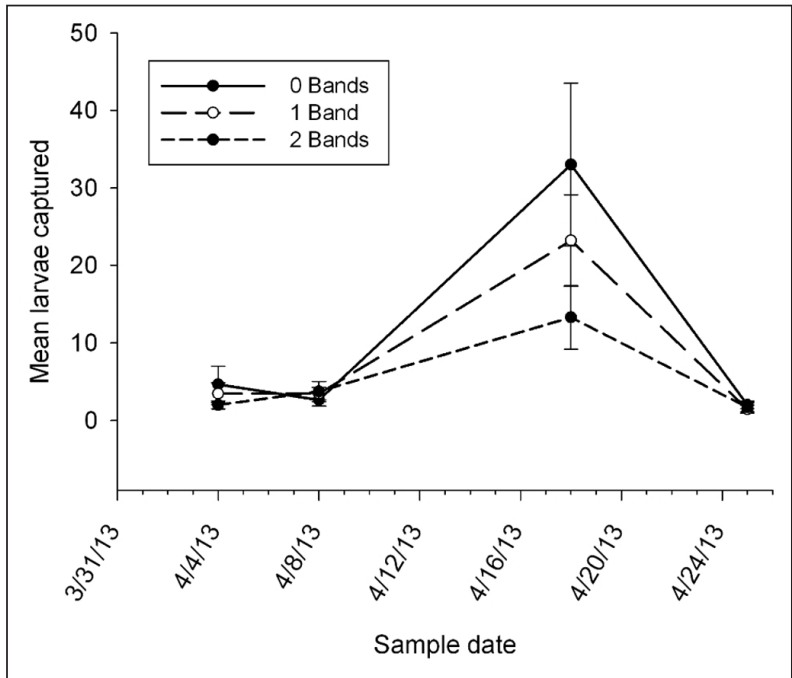

Figure 3. Mean ( \pm SEM) caterpillars per beat sample of two 60 $\mathrm{cm}$ branches from each.

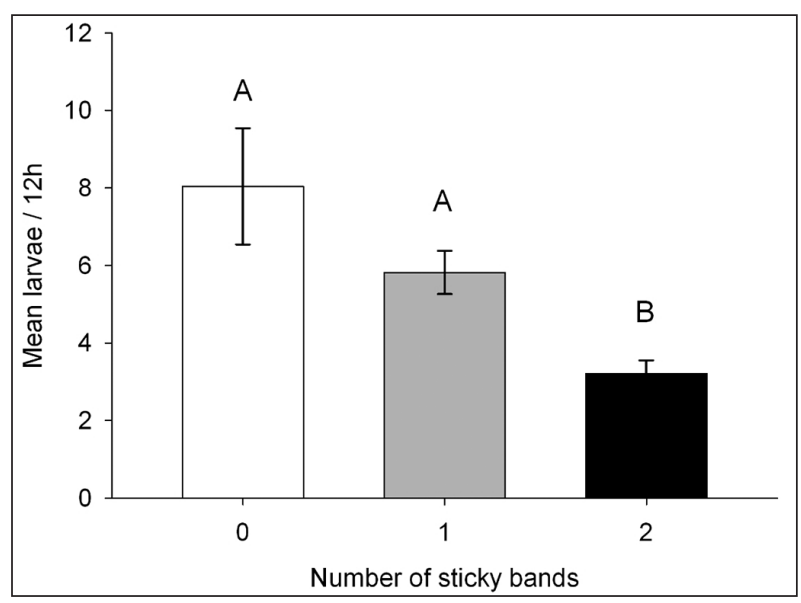

Figure 4. Mean $( \pm$ SEM) cankerworm larvae captured in trays per 12 hours. 
kerworm larvae per branch were not significantly correlated with percent canopy defoliation on April $18(\mathrm{r}=-0.159 ; \mathrm{n}=33 ; P=0.376)$ or April 25 $(\mathrm{r}=-0.030 ; \mathrm{n}=33 ; P=0.868)$. This indicates that counting cankerworm larvae on branch clippings is not an effective way to predict canopy, defoliation later in the season. Cankerworm larvae and defoliation can be clumped within a canopy so a large sample would be necessary to predict density accurately. The density of gypsy moth larvae is also estimated by passive collection of frass pellets rather than direct sampling for this reason (Liebold and Elkinton 1988). Researchers could only sample the lowest branches of many trees with a $4.9 \mathrm{~m}$ pole pruner, so it was impossible to get representative samples from multiple locations in the canopy.

Percent canopy defoliation did not differ due to band treatment (Figure 5; $\mathrm{F}_{2,20}=0.81 ; P=0.460$ ). Percent canopy defoliation (arcsin $\sqrt{\mathrm{x}}$ transformed) was significantly positively correlated with the season-long mean of larvae captured per 12 hours $(\log (\mathrm{x}+1)$ transformed $)$ in trays $(\mathrm{r}=0.374 ; \mathrm{n}=33$; $P=0.032)$. Untransformed data were also correlated (Figure 6; $\mathrm{r}=0.325 ; \mathrm{n}=33 ; P=0.065$ ). Percent canopy defoliation was correlated with the number of larvae captured on each of the first three tray sampling dates (April $18 \mathrm{r}=0.338 ; \mathrm{n}=33 ; P=$ 0.054; April 19 $\mathrm{r}=0.477 ; \mathrm{n}=33 ; P=0.005$; April 20, $\mathrm{r}=0.351 ; \mathrm{n}=26 ; P=0.078)$ and with the mean of these dates (Figure 6; $\mathrm{r}=0.392 ; \mathrm{n}=33 ; P=0.024$ ).

Cankerworm defoliation can be predicted by the number of female moths captured by sticky bands on sample trees in a forest (Kegg

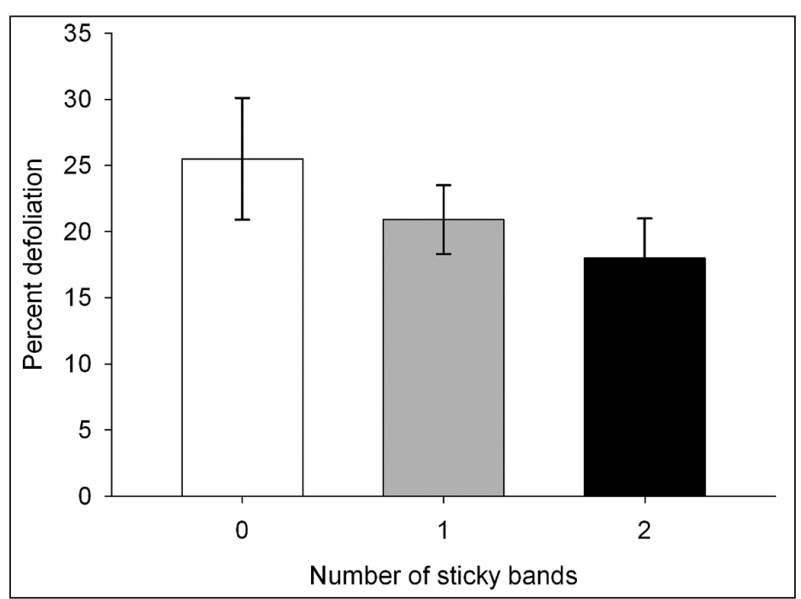

Figure 5. Mean $( \pm S E M)$ percent canopy defoliation estimated from the ground in $10 \%$ increments.

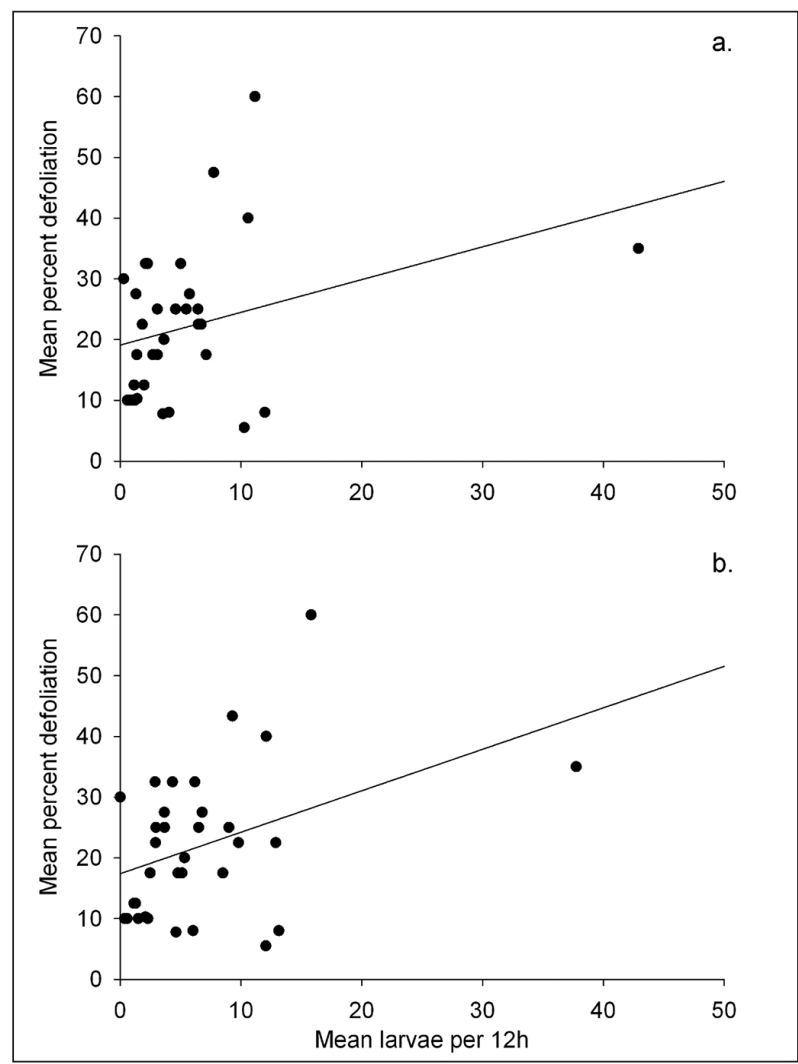

Figure 6. Correlation between the mean percent canopy defoliation and the number of larvae captured in trays (per 12 hours) over the whole season (a) and on the first the first three sample dates (b).

1967). At least one city has used this relationship to develop an action threshold to determine which parts of a city will need insecticide applications to prevent unacceptable levels of defoliation (Eirich 2008). Researchers of the current study found that monitoring cankerworm abundance with trays of soapy water just after egg hatch could be a useful way to predict defoliation and whether insecticide applications are necessary. More research would be required to develop an action threshold based on tray captures. Since larvae only feed for $4-6$ weeks, monitoring cankerworm abundance after egg hatch does not leave much time to make an insecticide application before defoliation occurs.

Research on cankerworms (La France and Westwood 2006), winter moths (Otvos and Hunt 1986), and gypsy moths (Thorpe et al. 1993) has typically found that sticky bands have little to no effect on defoliation, in spite of capturing many moths or larvae. Cankerworms can lay over 200 eggs each. In the current study, two sticky bands 
prevented more than 900 moths per tree from laying eggs in the crown. This led to small differences in larval abundance and had no effect on defoliation between treatments. It is impossible to know if blocking crevices under the sticky bands would have reduced the number of moths traversing the bands, larval abundance, or defoliation. Studies that blocked crevices beneath bands also found that bands did not reduce larval abundance or defoliation (Blumenthal and Hoover 1986; Otvos and Hunt 1986; Thorpe et al. 1993; Thorpe and Ridgway 1994; La France and Westwood 2006). Estimating defoliation in $10 \%$ increments was probably not sensitive enough when the average tree was less than 25\% defoliated. However, since larval density and defoliation are positively correlated, the study authors predict that sticky bands may have more benefit when populations are large and defoliation is high. This is supported by the only study to find that sticky bands reduced defoliation by a lepidopteran pest. Blumenthal (1983) found that bands reduce gypsy moth defoliation of oaks by up to $47 \%$ when defoliation of unbanded trees was close to $100 \%$.

This study is only the second study to test sticky bands specifically for cankerworm management. Although researchers did not find direct reductions in defoliation due to banding, larval abundance, which is correlated with defoliation, was reduced. Despite having little scientific support, municipalities often deploy thousands of sticky bands to help reduce cankerworm damage and insecticide applications (La France and Westwood 2006; Eirich 2008). Sticky bands may have benefits when deployed on a citywide or landscape scale that cannot be detected in small-scale studies. Future studies should investigate how the geographic scale of banding programs and outbreak severity affect sticky band efficacy against cankerworms.

Acknowledgments. The authors thank George Washburn, Allie Stewart, Uchenna Nwoko, and Andrew Ernst for field help and Robert Bradley from NCSU Grounds Maintenance for his cooperation. Comments from two anonymous reviewers and the editor improved the clarity of this manuscript. This work was funded, in part, by a North Carolina State University, Undergraduate Research Grant to Noukoun Chanthammavong and North Carolina State University Department of Entomology.

\section{LITERATURE CITED}

Baker, W.L. 1972. Eastern Forest Insects. United States Department of Agriculture, Forest Service miscellaneous publication no. 1175.

Blumenthal, E.M. 1983. Gypsy moth defoliation reduction using mechanical barrier devices. Melsheimer Entomological Series 33:21-30.

Blumenthal, E.M., and C.R. Hoover. 1986. Gypsy moth (Lepidoptera: Lymantriidae) population control using mechanical barriers and contact insecticides applied to tree stems. Journal of Economic Entomology 79:1394-1396.

Britton, W.E. 1900. On the banding of trees to prevent injury by the fall cankerworm. Report of the Connecticut Agricultural Experiment Station.

Cole, H., D. Barry, and D.E.H. Frear. 1967. DDT levels in fish, streams, stream sediments, and soil before and after DDT aerial spray application for fall cankerworm in northern Pennsylvania. Bulletin of Environmental Contamination \& Toxicology 2:127-146.

Collins, C.W., and C.E. Hood. 1920. Gipsy (sic) moth tree banding material: How to make, use, and apply it. Bulletin 899 of the United States Department of Agriculture. Washington, D.C.

Deane, S. 1797. The New England Farmer or Georgical Dictionary, 2nd Edition. Worcester, Massachusetts, U.S.

Eirich, R. 2008. Establishing action thresholds for control of cankerworms in Regina, Saskatchewan, Canada. Arboriculture \& Urban Forestry 34:66-73.

Feeny, P. 1970. Seasonal changes in oak leaf tannins and nutrients as a cause of spring feeding by winter moth caterpillars. Ecology 51:565-581.

Feeny, P. 1976. Plant apparency and chemical defense. Recent Advances in Phytochemistry 10:1-40.

Haukioja, E., P. Niemela, and S. Siren. 1985. Foliage phenols and nitrogen in relation to growth, insect damage, and ability to recover after defoliation in the mountain birch Betula pubescens ssp. tortuosa. Oecologia (Berlin) 65:214-222.

Haukioja, E., P. Niemela, L. Iso-Iivari, H. Ojala, and E. Aro. 1978. Birch leaves as a resource for herbivores. I. Variation in the suitability of leaves. Reports from the Kevo Subarctic Research Station 14:5-12.

Hiratsuka, Y., D.W. Langor, and P.E. Crane. 1995. A field guide to forest insects and diseases of the Prairie Provinces. Special report 3. Natural Resources Canada, Canadian Forest Service, Northwest Region, Northern Forestry Centre, Edmonton, Alberta. 297 pp.

Johnson, W.T., and H.H. Lyon. 1991. Insects that Feed on Trees and Shrubs, 2nd Edition. Cornell University Press, Ithaca, New York, U.S. pp. 142-143.

Kegg, J.D. 1967. Sampling techniques for predicting fall cankerworm defoliation. Journal of Economic Entomology 60:889-890.

Kulman, H.M. 1971. Effects of insect defoliation on growth and mortality of trees. Annual Review of Entomology 16:289-234.

La France, K.R., and A.R. Westwood. 2006. An assessment of tree banding techniques to capture cankerworm defoliators of elm and ash trees in Winnipeg, Manitoba, Canada. Arboriculture \& Urban Forestry 1:11-17. 
Liebhold, A.M., and J.S. Elkinton. 1988. Techniques for estimating the density of late-instar larval gypsy moth, Lymantria dispar (Lepidoptera: Lymantriidae), populations using frass drop and frass production measurements. Environmental Entomology 17:381-384.

Lyttle, S. 2012. Cankerworms infestation worst in a generation? Charlotte Observer. Accessed 08/05/2013. <www.charlotteobserver.com/2012/03/28/3134480/cankerworms-return-worseoutside.html>

Miller, J.C. 1990. Field assessment of the effects of a microbial pest control agent on nontarget Lepidoptera. American Entomologist 36:135-140.

Miller, K.K., and M.R. Wagner. 1989. Effects of Pandora moth (Lepidoptera: Saturniidae) defoliation on growth of ponderosa pine in Arizona. Journal of Economic Entomology 82:1682-1686.

Minott, C.W., and I.T. Guild. 1925. Some results of defoliation of trees. Journal of Economic Entomology 18:345-348.

Naidoo, R., and M.J. Lechowicz. 2001. Effects of gypsy moth on radial growth of deciduous trees. Forest Science 47:338-348.

Otvos, I.S., and R.S. Hunt.1986. Evaluation of three types of barriers to trap winter moth Lepidoptera: Geometridae) adults. Journal of the Entomological Society of British Columbia 83:27-30.

Porter, L.A., and C.H. Alden. 1924. The cankerworms. Bulletin 1238 of the U.S. Department of Agriculture. Washington, D.C.

Potter, D.A., and C.T. Redmond. 1989. Early spring defoliation, secondary leaf flush, and leafminer outbreaks on American holly. Oecologia 81:192-197.

Rhoades, D.F. 1983. Herbivore population dynamics and plant chemistry. pp. 155-220. In: R.F. Denno and M.S. McClure (Eds.). Variable plants and herbivores in natural and managed systems. Academic Press, New York City, New York, U.S.

Riley, C.V, A.S. Packard, and C. Thomas. 1883. Canker worms (sic): Being an account of the two species injurious to fruit and shade trees, with practical suggestions. Third Report of the United State Entomological Commission. United States Department of Agriculture. Washington, D.C.

Shaffer, J. 2012. Bumper crop of inchworms coats the Triangle. Raleigh News and Observer. Accessed 08/05/2013. <www. newsobserver.com/2012/03/28/1963991/bumper-crop-ofinchworms-coats.html>
Thorpe, K.W., and R.L. Ridgway. 1994. Effects of trunk barriers on larval gypsy moth (Lepidoptera: Lymantriidae) density in isolated and contiguous oak trees. Environmental Entomology 23:832-836

Thorpe, K.W., R.E. Webb, R.L. Ridgway, L. Venables, and K.M. Tatman. 1993. Sticky barrier bands affect density of gypsy moth (Lepidoptera: Lymantriidae) and damage in oak canopies. Journal of Economic Entomology 86(5):1497-1501.

Tobin, P.C., B.B. Bai, D.A. Eggen, and D.S. Leonard. 2012. The ecology, geopolitics, and economics of managing Lymantria dispar in the United States. International Journal of Pest Management 58:195-210.

Turner, N. 1963. Effect of defoliation by the gypsy moth. Bulletin 658 of the Connecticut Agriculture Experiment Station. 30 pp.

White, J.A., and T.G. Whitham. 2000. Associational susceptibility of cottonwood to box elder herbivore. Ecology 81:1795-1803.

White, T.C.R. 1984. The abundance of invertebrate herbivores in relation to the availability of nitrogen in stressed food plants. Oecologia 63:90-105.

Wright, S.L., R.W. Hall, and J.W. Peacock. 1989. Effect of simulated insect damage on growth and survival of northern red oak (Quercus rubra L.) seedlings. Environmental Entomology 18:235-239.

Chanthammavong Noukoun

North Carolina State University

Campus Box 7613

Raleigh, North Carolina 27695, U.S.

Gregory Bryant

North Carolina State University

Campus Box 7613

Raleigh, North Carolina 27695, U.S.

Steven D. Frank (corresponding author)

North Carolina State University

Campus Box 7613

Raleigh, North Carolina 27695, U.S.

sdfrank@ncsu.edu 
Zusammenfassung. Eine Entlaubung durch Fraßinsekten kann das Baumwachstum reduzieren und erhöht die Sterberate sowie das Gefressenwerden der Nachbarbäume. In Nord-Karolina sind Herbst- und Frühlingsfrostspanner bedeutende frühsaisonale Entlauber und haben sich in den letzten Jahren mittlerweile überall ausgebreitet. Die Weibchen der erwachsenen Herbst- und Frühlingsfrostspanner haben keine Flügel und klettern am Stamm hoch, um sich zu paaren und Eier abzulegen. Daher können Klebestreifen aus Papierbanderolen, die mit TangleFoot ${ }^{\mathrm{sx}}$ bestrichen sind, die weiblichen Motten daran hindern, den Baum zu erklimmen, die Eiablage zu verhindern und damit die Larvenanzahl und den entstehenden Fraßschaden zu vermindern. Die Autoren hypothetisieren, dass die Klebestreifen die Larven der Frostspanner und den Fraßschaden in der Krone im Vergleich zu unbehandelten Bäumen dezimieren. Um diese Hypothese zu überprüfen, wurde die Anzahl der Larven und der Grad der Entlaubung an mit keinem, einem oder zwei Bändern versehenen Weideneichen gemessen. Dabei kam heraus, dass die Bäume mit zwei Bändern durchschnittlich 38,69 \% mehr Motten fingen als die Bäume mit nur einem Klebestreifen. In der Konsequenz hatten die Bäume mit zwei Bändern weiniger Larven im Laub. Man fand heraus, dass die Anzahl der Larven, gemessen im Frühling in einer Fangschale mit Seifenwasser, mit dem Grad der Entlaubung am Ende der Vegetationsperiode korreliert werden konnte. Dennoch beeinflussten die Bänder nicht die gesamte Kronenentlaubung. Obwohl viele Städte diese Klebestreifen zur Frostspannerbekämpfung einsetzen, können die Autoren keinen Beweis für ihre Effizienz finden, wenn die Entlaubung gering ist.
Resumen. La defoliación por insectos puede reducir el crecimiento del árbol, incrementa la mortalidad y aumentar la defoliación de las plantas vecinas. En Carolina del Norte, EE.UU., las larvas de otoño (Alsophila pometaria) y de primavera (Paleacrita vernata) son importantes defoliadores de principios de temporada y se han vuelto muy comunes en los últimos años. Los gusanos adultos femeninos de otoño y primavera no son alados y suben por los troncos de árboles para aparearse y depositar masas de huevos. Por lo tanto, la envoltura con bandas de papel adhesivas alrededor de los árboles, cubriéndolos con Tanglefoot ${ }^{\mathrm{tm}}$, pueden interceptar las hembras lo que impide la oviposición y la reducción de la abundancia de larvas posterior y la defoliación. Los autores plantean la hipótesis de que las bandas adhesivas reducen las larvas y la defoliación en el dosel, en comparación con los árboles sin anillar. Para probar esta hipótesis, se midieron la abundancia de larvas y la defoliación en encinos con cero, una y dos bandas. Se encontró que los árboles con dos bandas capturaron un promedio de $38,69 \%$ más larvas que los árboles con una sola banda. Como consecuencia, los árboles de dos bandas tenían menor cantidad de larvas en la copa. Se encontró que la abundancia de larvas, muestreadas a principios de la temporada con pruebas de agua jabonosa, se correlacionó con la defoliación de la copa al final de la temporada. Sin embargo, las bandas no afectaron a la defoliación total de la copa. Aunque muchas ciudades utilizan bandas adhesivas como parte del manejo de las larvas, los autores no encontraron evidencia de su eficacia cuando la defoliación es baja. 